\title{
A new species of Lobelia L. (Campanulaceae: Lobelioideae) from the Arunachal Pradesh part of the Eastern Himalaya in India
}

\author{
Dipankar Borah, Sumpam Tangjang ${ }^{1}$ and A. P. Das \\ Department of Botany, Rajiv Gandhi University, Rono Hills, Doimukh 791112, Arunachal Pradesh, India \\ E-mails:dipankarborah085@gmail.com; sumpam@gmail.com; apdas.nbu@gmail.com \\ ${ }^{1}$ Corresponding author
}

[Received 22.01.2018; Revised 29.01.2018; Accepted 10.02.2018; Published 30.06.2018]

\begin{abstract}
Anew species, Lobelia arunachalensis D.Borah, S.Tangjang \& AP. Das has been recognized and named from the Lower Subansiri district of Arunachal Pradesh, which is situated on the easternmost part of the Indian Himalaya. The species is morphologically quite close to Lobelia nicotianifolia Roth ex Roem. \& Schult. Detailed description, photographs of different plant parts and reference to Type specimen has been provided.
\end{abstract}

Key words: Lobelia arunachalensis, New species, Arunachal Pradesh, Eastern Himalaya

\section{INTRODUCTION}

Lobelia L. is the second largest genus of Campanulaceae Juss. Among the 84 genera in the family, 29 are placed under the subfamily Lobelioideae Burnett. The members of the group show great diversity in their size, habit, morphology, reproductive strategies, and chromosome numbers (Lammers 2011).

Linnaeus established the genus Lobelia in his Species Plantarum (1753) and presented 25 species under it. C.B. Clarke (1881) divided the genus Lobelia into three sections as Holopogon, Isolobus and Rhyncopetalum. Later on, Lammers (2011) recognized eighteen sections in the genus rendering it easier to study (Biju et al.2016). The genus is widespread throughout the world consisting of over 400 species (Lammers 2011). Singh and Diwakar (2010) recorded the occurrence of six species of Lobelia in India. Biju et al. in 2016 identified and named one new species from the state of Kerala that makes the total of seven species of the genus for the flora of this country. In addition, some introduced ornamental species of Lobelia are also available in Indian gardens (Singh \& Diwakar 2010). These seven species can be easily recognized based on their morphology and growth form.

The richness of the flora of Arunachal Pradesh is well known that is covering the easternmost part of the Eastern Himalaya (Hajra et al. 1996). The area of this state of NE India was earlier an integrated part of the state of Assam and was recognised as a separate state on $20^{\text {th }}$ February 1987 (https://en.wikipedia.org/wiki/Arunachal_Pradesh\#Early_history). In their Assam Flora, Kanjilal et al. (1939) did not record any species of Lobelia. However, Giri et al. (2008) recorded three species from Arunachal Pradesh, namely Lobelia doniana Skottsb., L. pyramidalis Wall. and L. rosea Wall. 
While inventorying the flowering dicots of Lower Subansiri district of Arunachal Pradesh [approximately between $92^{\circ} 40^{\prime}$ and $94^{\circ} 21^{\prime}$ East Longitude and $26^{\circ} 55^{\prime \prime}$ and $28^{\circ} 21^{\prime}$ North Latitudes], India, the authors came across the population of an interesting species of Lobelia in its reproductive stage along the hill slopes on the roadside [ $\pm 962 \mathrm{~m}$ amsl]. After detailed study of the specimen and persuasion of different literature [C.B. Clarke (1881); Singh \& Diwakar (2010); Lammers (2011); Biju et al. (2016)], the plant is now recognised as a new species of Lobelia belonging to the sect. Rhyncopetalum. The new species is quite similar to Lobelia nicotianifolia Roth ex Roem. \& Schult. with some variation in stable and important characters.

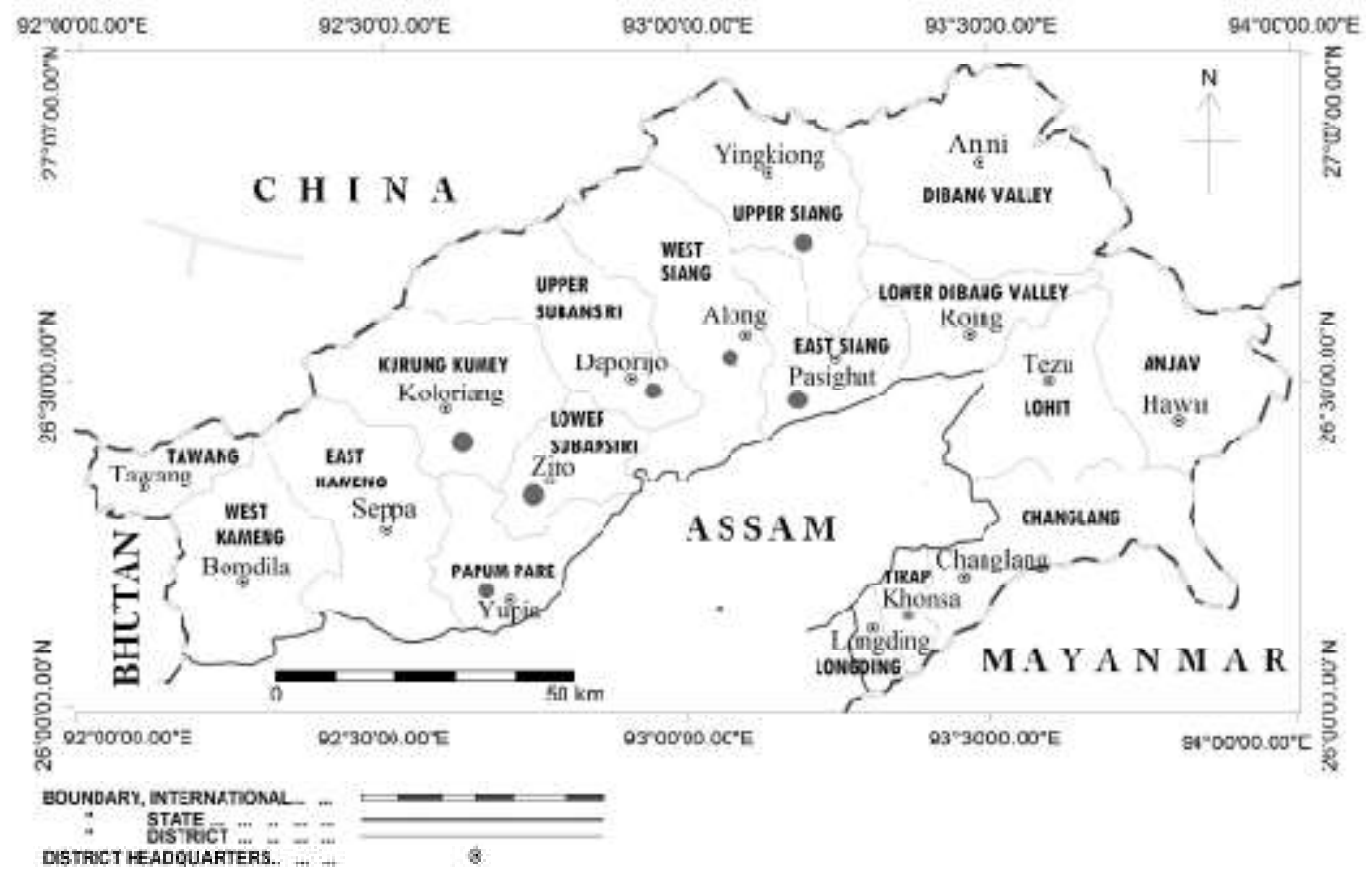

Figure 1. Districts of Arunachal Pradesh [Source: http://www.mdoner.gov.in/content/ arunachal-pradesh-1]

\section{Taxonomy}

Lobelia arunachalensis D.Borah, S.Tangjang \& AP Das, Sp. nov. [PLATE - I]

\section{Diagnosis}

Lobelia arunachalensis is very similar to Lobelia nicotianifolia in its habit and flower structure. However, the new species differs from $N$. nicotianifolia in its life-span, height, leaf structure, size of the flower and shape of the fruit. Flowering period of these two species are abruptly different even in the same area. The differences between these two species has been presented in Table 1.

Types: INDIA. Arunachal Pradesh: Lower Subansiri District, Potin, $27^{\circ} 33288.62^{\prime \prime} \mathrm{N}$ $93^{\circ} 79279.743$ E, 16 September 2017, D. Borah, S. Tangjang \& AP. Das 034 (Holotype: CAL; Isotypes: ASSAM, ARUN)

Herbs, annual, erect, $0.3-1.4 \mathrm{~m}$ tall. Stems $0.2-0.5 \mathrm{~cm}$ in diameter, terete, producing only flowering branches above; branches densely but minutely villous. Leaves alternate, at least lower ones petiolate; petiole $0.2-1 \mathrm{~cm}$; lamina broadly lanceolate, $1-8.5 \times 0.2-1.5 \mathrm{~cm}$, 
96 New species of Lobelia from Arunachal Pradesh

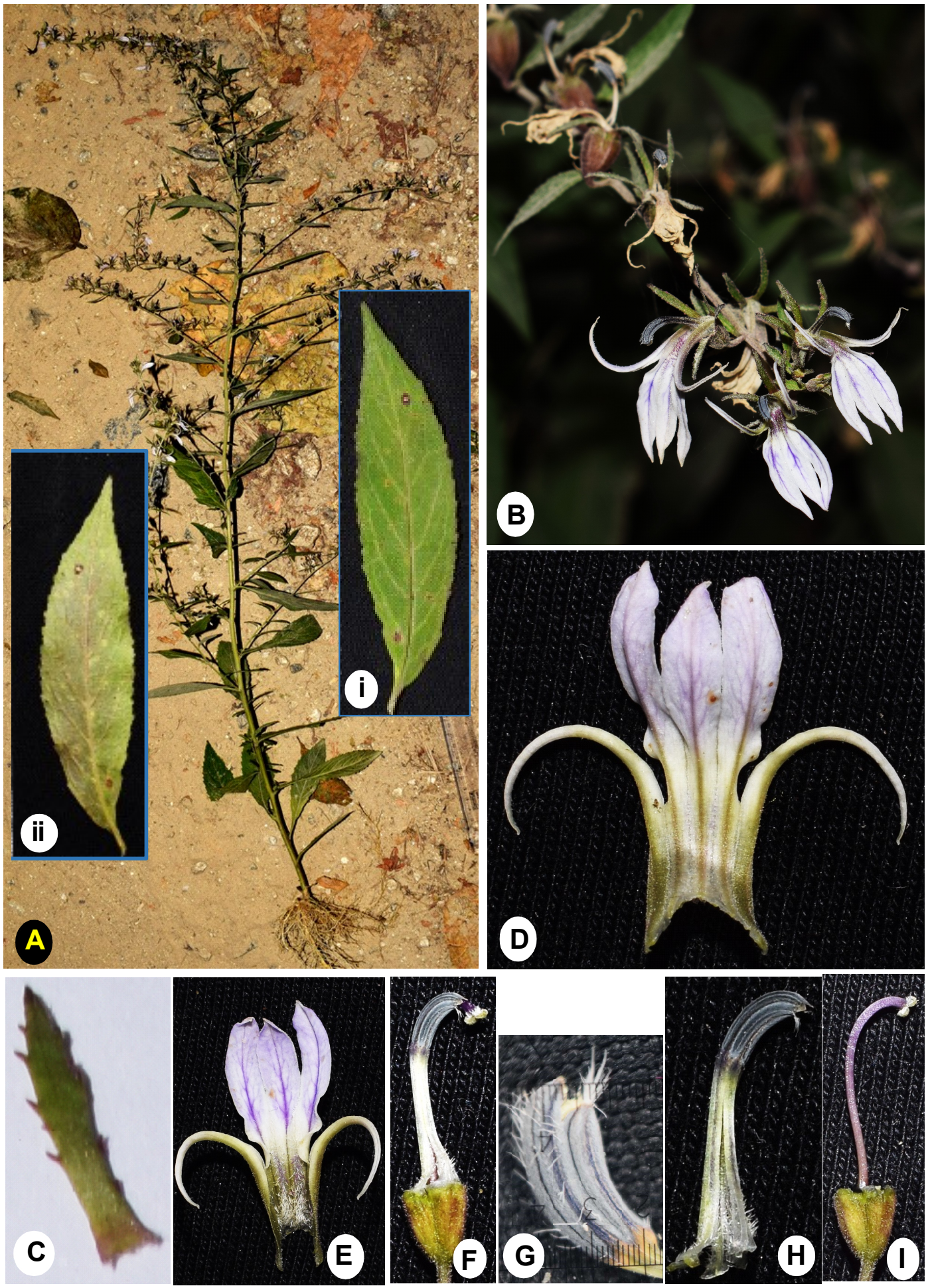

PLATE - I: Lobelia arunachalensis: A. Entire plant; B. Part of inflorescence; C. Calyx lobe; D. Corolla from outside; E. Inside of corolla; F. Staminal column along with gynoecium; G. Synangium with strigose barbs; H. United filaments and anthers; I. Gynoecium. Insets: Leaf - (i) upper \& (ii) lower surfaces 
double dentato-serrate, acuminate, base slightly unequal, gradually narrowing into the petiole; lateral veins 8 , arching upward densely villous above, sparsely villous below. Racemes lax, terminal on branches and main shoot, leafy, secund, many flowered. Bracts linear to leaflike, gradually smaller upwards, upper ones shorter but lower ones longer than flowers. Pedicels $4-6 \mathrm{~mm}$, slender, terete. Flowers epigynous, zygomorphic, $1.8-2 \mathrm{~cm}$ long. Calyx lobes long subulate-lanceolate, $4-8 \times 0.5-1 \mathrm{~mm}$, mid-vein prominent, both surfaces sparsely villous, green, herbaceous, glandular serrate, persistent; serrations $4-6$, long and subulate. Corolla split to the base on the anterior side and spreading on the posterior side, 5 lobed one sided (unilabiate but not rayed), 2 lateral lobes slender more deeply dissected, curved, spreading outward the lips, $17 \mathrm{~mm}$ long; middle three lobes nearly equal, not dissected up to the tube but each lobe acuminate and with a median longitudinal depression, white to purplish-white; corolla tube open above, $0.6-0.8 \mathrm{~mm}$ long, exterior surface glabrous, strigose inside base towards the anterior surface. Filaments connate from little above the base; filament tube glabrous or sparsely shortly strigose below, $7-10 \mathrm{~mm}$ long; anthers connate, $2.5-3 \mathrm{~mm}$ long, upper 3 anthers sparsely strigose, lower 2 anthers barbed at the tip. Gynoecium: style 1, 10 - $15 \mathrm{~mm}$ long, slightly curved above, stigma 2-lobed, peeping out from tip of synangium. Capsules conical oblong, $8-10 \times 3-5 \mathrm{~mm}$. Seeds ovoid, striate, lenticular, $\pm 0.5 \mathrm{~mm}$ long.

Flowering and fruiting: August to December

Etymology: The species is named after the biodiversity-rich state Arunachal Pradesh of India where from the new species has been recognised.

Distribution: So far, the species is known to grow only in the Lower Subansiri districts of Arunachal Pradesh, India.

Table 1. Comparison of Lobelia nicotianifolia and Lobelia arunachalensis.

\begin{tabular}{|l|l|l|}
\hline Character & \multicolumn{1}{|c|}{ Lobelia nicotianifolia } & \multicolumn{1}{|c|}{ Lobelia arunachalensis sp. nov } \\
\hline Habit & Up to $6 \mathrm{~m}$ tall & Plants up to $1.4 \mathrm{~m}$ tall \\
\hline Life-span & Biennial & Annual \\
\hline Leaf & $\begin{array}{l}\text { Basal leaves numerous, up to } 31 \mathrm{~cm} \\
\text { long }\end{array}$ & Basal leaves few, only up to $8.5 \mathrm{~cm}$ long \\
\hline Stem & $\begin{array}{l}\text { Glabrous or pilose or pubescent, } \\
\text { stout }\end{array}$ & Densely but minutely villous, slender \\
\hline Pedicel & Pedicels $0.5-3.5 \mathrm{~cm}$ long & Pedicel $0.4-0.6 \mathrm{~cm}$ long \\
\hline $\begin{array}{l}\text { Flowering } \\
\text { time }\end{array}$ & August - April & August - December \\
\hline Flowers & Over $3 \mathrm{~cm}$ long & Up to $2 \mathrm{~cm}$ long \\
\hline Calyx lobes & $\begin{array}{l}\text { Linear to linear-lanceolate, up to } 20 \\
\text { mm long, denticulate or entire, } \\
\text { glabrous or pubescent; lobes in } \\
\text { terminal flowers extend beyond the } \\
\text { corolla }\end{array}$ & $\begin{array}{l}\text { Subulate-lanceolate, up to } 8 \mathrm{~mm} \text { long, } \\
\text { glandular-serrate, both sides villous; } \\
\text { lobes in terminal flowers cover half of } \\
\text { the corolla }\end{array}$ \\
\hline Corolla & Tube up to $3 \mathrm{~cm}$ long & Tube up to $0.8 \mathrm{~cm}$ \\
\hline Stamens & $\begin{array}{l}\text { Filaments } 7-18 \mathrm{~mm}, \text { lower one- } \\
\text { third part free; anthers glabrous or } \\
\text { pubescent or pilose, }\end{array}$ & $\begin{array}{l}\text { Filaments } 7-10 \mathrm{~mm} \text {, lower one-fifth } \\
\text { part free; anthers sparsely pubescent } \\
\text { above }\end{array}$ \\
\hline Style & Up to $21 \mathrm{~mm}$ long & Up to $15 \mathrm{~mm}$ long \\
\hline Capsule & Sub-globose or globose or ovoid & Oblong with conical base \\
\hline
\end{tabular}


98 New species of Lobelia from Arunachal Pradesh

Affinities: Lobelia arunachalensis is allied to Lobelia nicotianifolia. The shape of lamina and corolla are identical in both the allies. A comparison of characters is provided in Table 1 for their easy distinction.

Conservation status: The presently known area of its distribution is a private land and its occurrence in any nearby reserved vegetation is yet to be confirmed.

\section{Acknowledgements}

Authors are grateful to Dr. T.G. Lammers and Dr. P. Biju for expressing their observation on the specimen. The first author is indebted to Neelam Gap and also to his parents for their continued and constant support.

\section{LITERATURE CITED}

Biju, P.; Josekutty, E.J. \& Augustine, J. 2016. A new species of Lobelia L. (Campanulaceae: Lobelioideae) from the lateritic plateau of northern Kerala, India. Webbia, J. Plant Tax. Geogr. Doi.org/10.1080/00837792.2016.1175734

Clarke, C.B. 1881. Lobelia L. In: Hooker, J.D. (ed.), The Flora of British India, Vol. III. L. Reeve \& Co Ltd, Ashford, Kent, London. Pp. 423 - 428.

Giri, G.S.; Pramanik, A. \& Chowdhery, H.J. 2008. Materials for the Flora of Arunachal Pradesh. Vol. - 2. Flora of India Series-2. Botanical Survey of India, Kolkata.

Hajra, P.K.; Verma, D.H. \& Giri, G.S. 1996. Materials to the Flora of Arunachal Pradesh. Vol. 1. Flora of India Series-2. Botanical Survey of India, Calcutta.

https://en.wikipedia.org/wiki/Arunachal_Pradesh\#Early_history

Kanjilal, U.N.; Kanjilal, P.C.; Das. A. \& Dey, R.N. 1939. Flora of Assam, Vol. 3, Assam Govt. Govt. Press, Shillong.

Lammers, T.G. 2011. Revision of the infrageneric classification of Lobelia L. (Campanulaceae: Lobelioideae). Ann. Miss. Bot. Gard. 98(1): $37-62$.

Linnaeus, C. 1753. Species Plantarum. Laurentius Salvius, Stockholm.

Singh, R.K. \& Diwakar, P.G. 2010. The genus Lobelia L. (Lobeliaceae) in India. Indian J. For. 33(4): $625-634$. 